\title{
JMR Appoints New Principal Editors, Reports on Upcoming Diamond Issue
}

Joumal of Materials Research added 11 new principal editors to its editorial board in May to address the growing number of manuscripts, on a wide variety of subjects, being submitted to the Journal. In the November $J M R$ alone, more than 35 papers will be published in a special section dealing with diamond and diamond-like materials.

"I am delighted that these 11 new principal editors have offered their expertise to $J M R$," said Walter L. Brown, Editor in Chief. "Having them join the 11 principal editors already involved with JMR will enable the Journal to continue to handle an expanding volume of important interdisciplinary materials research in a timely and effective manner."

The new editors will review papers in such areas as ordered alloys, inorganic materials synthesis and reactivity, defects in metals and semiconductors, multilayered metallic thin films, transport properties in inorganic and organic solids, high $T_{c}$ superconductors, and interfacial phenomena and metal-semiconductor interface.

The new principal editors are Prof. John R. Arthur (Oregon State University), Prof.
Patrick K. Gallagher (Ohio State University), Prof. Ulrich M. Goesele (Duke University), Dr. A. Lindsay Greer (Cambridge University, England), Prof. Jean-Paul Issi (Unité de Physico-Chimie et de Physique des Matériaux, Belgium), Dr. Heiko Kleykamp (Kernforschungszentrum Karlsruhe, West Germany), Prof. Max G. Lagally (University of Wisconsin), Dr. C.T. Liu (Oak Ridge National Laboratory), Prof. William D. Nix (Stanford University), Dr. Julia M. Phillips (AT\&T Bell Laboratories), and Prof. John $\mathrm{H}$. Weaver (University of Minnesota).

"When the Journal was first created, the Materials Research Society asked itself whether it could assemble a cadre of editors for $J M R$ who would simultaneously maintain the highest manuscript reviewing standards and be recognized and respected by readers and authors. The answer was 'yes,' and looking at our new group of editors, the answer clearly continues to be 'yes," Brown said.

Brown also said he was pleased with the growing involvement of Werner Lutze (Kernforschungszentrum Karlsruhe) and Shigeyuki Sömiya (The Nishi Tokyo Univer- sity), who were recently named JMR Associate Editors in Europe and Japan, respectively. Both associate editors have been overseeing the review of manuscripts from an increasing number of authors who are finding it more convenient to submit papers directly to the associate editor in their region. Additional principal editors will be appointed in the near future to handle manuscript reviews for Lutze and Somiya.

\section{Diamonds to be Focus of November JMR}

As the result of an overwhelming response to a call for papers mailed out in February, more than 300 pages dealing with recent research on diamonds and diamond-like materials will be published in the November $J M R$ - although papers on other topics will also be published. The articles focus on the interdisciplinary aspects of research in this field including diamond and diamond-like materials synthesis, growth, characterization and processing.

Editor's Note: See the October MRS BULLETIN for a complete list of November JMR articles.

\section{How did you get this MRS BULLETIN?}

MRS Members receive the MRS Bulletin automatically. If you don't but would like to, join MRS in 1991. For $\$ 65$, not only will you receive 12 monthly issues of the Bulletin, but also:

- 12 monthly issues of Journal of Materials Research*

- lowest available prices on MRS books and videotapes

- calls for papers and preliminary programs for MRS meetings

- voting privileges-a voice in Society policy

- the 1991 MRS Membership Directory

- job placement services at MRS meetings

and most importantly, valuable professional interaction with your colleagues in allied materials disciplines. For more information contact: MRS Membership Department, 9800 McKnight Road, Pittsburgh, PA 15237; telephone (412) 367-3003; FAX (412) 367-4373

*MRS Student Members may subscribe to JMR for $\$ 15$ in addition to their $\$ 20$ member dues. 


\section{Journal of Materials Research Articles in the October 1990 Issue (Nol. 5 No. 10)}

\section{Rapid Communications}

Amorphous Lead Iron Tungstate Prepared by Twin-Roller Quenching, by N.K. Kim and D.A. Payne.

The Preparation and Processing of Bulk Superconducting Ceramic $\mathrm{Nd}_{2-x} \mathrm{Ce}_{x} \mathrm{CuO}_{4-\mathrm{y}}$ by M.E. Lopez-Morales, R.J. Savoy, and P.M. Grant.

\section{Articles}

A Dislocation Based Analysis of Continuum Mechanical and Microscopic Local Stresses During Cyclic Deformation of Copper, by Mukesh Jain.

Acoustic Emission Study of Microcracking in 123-Type Ceramic Superconductors, by T.J. Richardson and L.C. De Jonghe.

Adhesion and Short-Range Forces Between Surfaces. I: New Apparatus for Surface Force Measurements, by Jacob N. Israelachvili and Patricia M. McGuiggan.

Adhesion and Short-Range Forces Between Surfaces. II: Effects of Surface Lattice Mismatch, by Patricia M. McGuiggan and Jacob N. Israelachvili.

An X-ray Fourier Line Shape Analysis in Cold-Worked Hexagonal Magnesium Base Alloys, by S.K. Chattopadhyay, S.K. Chatterjee, and S.P. Sen Gupta.

Brazing of Aluminum Nitride Substrates, by M.G. Norton, J.M. Kajda, and B.C.H. Steele.

Deuterium Clusters in a Strained Palladium Lattice, by Vittorio Rosato and Fabrizio Cleri.

High Temperature Extrusion Behavior of Fine Grain $\mathrm{ZrO}_{2}$, by B.J. Kellett.

Indentation Load Relaxation Experiments With Indentation Depth in the Submicron Range, by W.R. LaFontaine, B. Yost, R.D. Black, and C.-Y. Li.

Kinetic Study and Modelling of the Solid-State Reaction $\mathrm{Y}_{2} \mathrm{Ba}$ $\mathrm{CuO}_{5}+3 \mathrm{BaCuO}_{2}+2 \mathrm{CuO}-2 \mathrm{YBa}_{2} \mathrm{Cu}_{3} \mathrm{O}_{6.5-\mathrm{x}}+x \mathrm{O}_{2}$, by NaeLih Wu, Ta-Chin Wei, Shau-Y Hou, and S-Yen Wong.

Low Temperature Phase Separation in $\mathrm{CeSi}_{1.86}$, by $\mathrm{R}$. Madar, B. Lambert, E. Houssay, C. Meneau d'Anterroches, J. Pierre, O. Laborde, J.L. Soubeyroux, A. Rouault, J. Pelissier, and J.P. Senateur.

Microstructural Interaction of $\mathrm{Y}_{2} \mathrm{Ba}_{4} \mathrm{Cu}_{8} \mathrm{O}_{16}$ Stacking Faults Within $\mathrm{Y}_{1} \mathrm{Ba}_{2} \mathrm{Cu}_{3} \mathrm{O}_{7-x}$, by A.F. Marshall, K. Char, R.W. Barton, A. Kapitulnik, and S.S. Laderman.
Phase Equilibria and Structural Chemistry in the Ternary Systems $\mathrm{M}-\mathrm{Si}-\mathrm{N}$ and $\mathrm{M}-\mathrm{B}-\mathrm{N}(\mathrm{M}=\mathrm{Al}, \mathrm{Cu}, \mathrm{Zn}, \mathrm{Ag}, \mathrm{Cd}, \mathrm{In}, \mathrm{Sn}$, $\mathrm{Sb}, \mathrm{Au}, \mathrm{T1}, \mathrm{Pb}, \mathrm{Bi})$, by F. Weitzer, K. Remschnig, J.C. Schuster, and P. Rogl.

Preparation of Perovskite Oxides for High $\mathrm{T}_{\mathrm{c}}$ Superconductor Substrates, by C.D. Brandle and V.J. Fratello.

Quantitative Analysis of Elastic Moduli of Tellurite Glasses, by R.A. El-Mallawany.

Quantitative Topographic Analysis of Fractal Surfaces by Scanning Tunneling Microscopy, by Morgan W. Mitchell and Dawn A. Bonnell.

Reaction Between Niobium and Silicon Carbide at 1373 K, by D.L. Yaney and A. Joshi.

Reduced 'Splashing Effect' in Laser Ablated Superconducting Thin Films Formed From a Melt-Quenched Non-Superconducting Amorphous Target, by E. Agostinelli, J. Bohandy, W.J. Green, B.F. Kim, F.J. Adrian, and K. Moorjani.

Silicide Precipitation and Silicon Crystallization in Nickel Implanted Amorphous Silicon Thin Films, by R.C. Cammarata, C.V. Thompson, C. Hayzelden, and K.N. Tu.

Simulation of Porosity Reduction in Random Structures, by P.B. Visscher and Joseph E. Cates.

Structural and Chemical Stability of Thin Films of Pt-Ga Intermetallic Compounds on GaAs(001), by Young K. Kim, Delroy A. Baugh, David K. Shuh, R. Stanley Williams, Larry P. Sadwick, and Kang L. Wang.

The Calculation of Stacking Fault Energies in Close-Packed Metals, by S. Crampin, K. Hampel, D.D. Vvedensky, and J.M. MacLaren.

The Infrared Transmission Spectra of Four Silicate Glasses Before and After Exposure to Water, by Roy D. Husung and Robert $H$. Doremus.

The Mechanism of Synthesis of Titanium Nitride by SelfSustaining Reactions, by S. Deevi and Z.A. Munir.

\section{Comments}

On the Deposition Mechanism of $\mathrm{Al}_{2} \mathrm{O}_{3}$ in the CVI Process For Forming Ceramic Composites, by Nyan-Hwa Tai and Tsu-Wei Chou.

For further information on any of these articles or to subscribe to Joumal of Materials Research, please contact the Materials Research Society, 9800 McKnight Road, Pittsburgh, PA 15237; telephone (412) 367-3003; telefax (412) 367-4373.

\section{Send manuscripts for consideration in JMR to any one of the following:}

- Dr. Walter L. Brown, Editor-in-Chief, Journal of Materials Research, Materials Research Society, 9800 McKnight Road, Pittsburgh, PA 15237; telephone (412) 367-9111; $\operatorname{fax}(412) 367-4373$.

- Dr. Werner Lutze, Kernforschungszentrum Karlsruhe, Postfach 3640, D-7500 Karlsruhe, West Germany; telephone 49-7247-824457; fax 49-7247-823927.

- Prof. Shigeyuki Sōmiya, Nishi Tokyo University, 3-7-19 Seijo, Setagaya, Tokyo 157, Japan; telephone 81-3-417-2866; fax 81-3-415-6619. 